\title{
Implementasi Kebijakan Ketahanan Pangan dan Gizi di Kabupaten Subang
}

\author{
Kusman Yuhana \\ Universitas Subang, Indonesia \\ Email : Kusmanyuhana.jurnal@gmail.com
}

\begin{abstract}
Abstrak
Tujuan dari penelitian ini adalah untuk mengetahui tentang Implementasi Kebijakan Gizi dan Ketahanan Pangan di Kabupaten Subang. Penelitian ini di Kabupaten Subang menggunakan metode deskriptif kualitatif. Pengumpulan data dilakukan langsung kepada informan yang telah ditentukan oleh penulis, kemudian hasilnya dibedakan dengan kode pertanyaan untuk memudahkan pengelolaan data. Kemudian untuk validitas data menggunakan triangulasi data atau sumber data yang ada. Adapun hasil penelitian ini menunjukkan bahwa kebijakan Implementasi gizi dan ketahanan pangan Kabupaten Subang belum optimal. standar dan ukuran kebijakan tidak optimal, karena dalam satu tahun hanya ada 3 atau 6 kecamatan dan di satu kecamatan hanya satu desa yang menerima bantuan yang menginginkannya, terkait dengan sumber daya kebijakan yang kurang optimal seperti fasilitas dan infrastruktur, sumber daya anggaran, dan sumber daya manusia yang tidak memiliki keahlian di bidang ketahanan pangan. Struktur yang terlibat dalam proses implementasi kebijakan nutrisi dan kebijakan ketua keamanan pangan atau dewan keamanan pangan tidak ada tindakan signifikan yang terlibat dalam proses implementasi kebijakan ketua atau dewan keamanan pangan dan pelaksana memiliki komitmen yang rendah. Kondisi ekonomi yang menjadi kelompok sasaran masih berpenghasilan rendah, mereka kurang berpartisipasi dan tidak dapat memanfaatkan fasilitas yang disediakan oleh pemerintah dan pelaksana tidak benar-benar memahami isi kebijakan gizi dan ketahanan pangan.
\end{abstract}

Kata kunci : kebijakan, implementasi, ketahanan pangan, ketahanan gizi

\section{Abstract}

The purpose of making this research is to find about the nutrition and food security Policy Implementation in the Subang regency. This research in Subang Regency uses qualitative descriptive methods. Data collection is done directly to the informants that have been determined by the author, then the results are distinguished by question codes to facilitate data management. Then for data validity using data triangulation or existing data sources. As for the results of this study indicate that the policy Implementation of nutrition and food security Subang regency is not optimal. the 
standard and size of the policy is not optimal, because in one year there are only 3 or 6 sub-districts and in one sub-district only one village that receives the assistance wants it, related to sub-optimal policy resources such as facilities and infrastructure, budget resources and human resources who don't have expertise in the field of food security. Structure involved in the policy implementation process nutrition and food security chairperson's policy or food security council there is no significant action involved in the implementation process of the chairperson's policy or the food security council and the implementors have low commitment. Economic conditions which are the target groups are still low income, they are less participating and cannot utilize the facilities provided by the government and the implementors do not really understand the contents of the policy of nutrition and food security.

Keywords : Policy, Implementation, food security, nutrition policy

\section{Pendahuluan}

Kebijakan publik merupakan alat untuk mencapai tujuan publik bukan tujuan orang perorangan atau golongan kelompok. Meskipun sebagai alat (tool) keberadaan kebijakan publik sangat penting dan sekaligus krusial. Penting karena keberadaannya sangat menentukan tercapainya sebuah tujuan meskipun ada beberapa tahapan lain yang harus terpenuhi untuk sampai pada tujuan yang dikehendaki. Krusial karena sebuah kebijakan yang di atas kertas telah dibuat melalui proses yang baik dan isinya berkualitas, namun tidak otomatis bisa dilaksanakan sesuai dengan apa yang diinginkan oleh pembuatnya. Beberapa tahun ini tentang kebijakan ketahanan pangan dan gizi menjadi perhatian yang menarik untuk dibahas, karena di Indonesia sedang gencar-gencarnya melakukan pembangunan sehingga banyak daerah-daerah yang melakukan pembangun industri. Sehingga beberapa lahan pertanian yang beralih fungsi menjadi lahan industri, dapat mengancam ketahanan pangan di Indonesia. Pangan merupakan kebutuhan mendasar bagi seluruh manusia untuk dapat melakukan aktivitas guna mempertahankan hidup. Pangan juga merupakan hak dasar bagi setiap warga negara. Jika ketersediaan pangan untuk memenuhi kebutuhan masyarakat tidak terpenuhi maka akan mengganggu kestabilan ekonomi. Pada KTT pangan sedunia tahun 1966 di Roma, para pemimpin negara dan pemeritah telah berjanji bahwa kemauan politik dan komitmennya untuk mencapai ketahanan pangan dan upaya untuk penghapusan kelaran di semua anggota negara.

Ketahanan pangan adalah kondisi terpenuhinya pangan bagi negara sampai dengan perseorangan, yang tercermin dari tersedianya pangan yang cukup, baik jumlah maupun mutunya, aman, beragam, bergizi, merata, dan terjangkau serta tidak bertentangan dengan agama, keyakinan, dan budaya masyarakat, untuk dapat hidup aktif, dan produktif secara berkelanjutan (UU Pangan No 18 Tahun 2012). Pada era desentralisasi ketahanan pangan telah menjadi salah satu urusan wajib pemerintah sebagaimana yang dinyatakan dalam Peraturan Pemerintah Nomor 38 Tahun 2007 tentang Pembagian Urusan 
Pemerintah antara Pemerintah, Pemerintah Provinsi, dan Pemerintah Kabupaten Kota. Pembangunan ketahanan pangan di Indonesia ditegaskan dalam Undang-Undang Pangan Nomor 18 Tahun 2012 pengganti UndangUndang Pangan Nomor 7 Tahun 1996, yang dibangun berdasarkan kedaulatan dan kemandirian. Hal ini menggambarkan jika ketahanan pangan suatu negara tidak mandiri dalam pemenuhan ketahanan pangan warga negaranya maka kedaulatan negara bisa terancam. Undang-Undang pangan ini menekankan dalam pemenuhan kebutuhan pangan di tingkat perorangan dengan memanfaatkan potensi sumber daya alam, manusia, sosial, ekonomi dan kearifan lokal secara bermanfaat.

Di Kabupaten Subang memiliki luas lahan pertanian untuk sawah sebesar 84. 570 hektar pada tahun 2014 (BPS Subang, 2014). Melihat kondisi dilapangan sekarang banyak lahan pertanian yang beralih fungsi menjadi lahan industri, perumahan, dan lain sebagainya, hal ini dapat mempengaruhi ketahanan pangan khususnya yang ada di Kabupaten Subang. Apalagi sekarang sedang dilakukannya pembangunan pelabuhan laut Internasional Patimban dikhawatirkan lahan pertanian banyak yang tergerus oleh industri. Tidak hanya tentang pemenuhan kebutuhan pangan saja yang harus terpenuhi, tapi pemerintah juga harus memperhatikan konsumsi makanan yang bergizi melalui kegiatan yang pernah dilakukan oleh pemerintah. Kebijakan Peraturan Pemerintah Republik Indonesia Nomor 17 Tahun 2015 Tentang Ketahanan Pangan dan Gizi yang di dalamnya meliputi ruang lingkup cadangan pangan, penganekaragaman pangan dan perbaikan gizi masyarakat, kesiapsiagaan dan penanggulangan krisis pangan, distribusi, perdagangan dan bantuan pangan.

Di Kabupaten Subang terdapat 10 Desa yang masyarakatnya mengalami stunting yaitu mulai dari Kecamatan Binong Desa Kediri dan Desa Mulyasari, Kecamatan Pusakanagara Desa Kotasari, Kecamatan Jalancagak Desa Bunihayu, Kecamatan Tanjungsiang Desa Kuwungluwuk, Kecamatan Compreng Desa Sukadana, Kecamatan Cibogo Desa Majasari, Kecamatan Legonkulon Desa Legonkulon dan Desa Mayangan, Kecamatan Serangpanjang Desa Cintamekar. Yang selanjutnya yaitu tidak hanya Kecamatan yang masyarakatnya mengalami stunting di Kabupaten Subang juga terdapat Kecamatan yang rawan pangan seperti Kecamatan Ciater, Kecamatan Cibogo, Kecamatan Cijambe, Kecamatan Cisalak, Kecamatan Jalancagak, Kecamatan Kasomalang, Kecamatan Sagalaherang, Kecamatan Serangpanjang, Kecamatan Subang, dan Kecamatan Tanjungsiang. Sumber daya manusia yang berkualitas sangat diperlukan untuk membangun masyarakat Subang dalam menghadapi persaingan di era global. Sehubungan dengan itu, pemerintah melalui program penganekaragaman konumsi pangan mengupayakan agar pola konsumsi pangan penduduk lebih beranekaragam dan seimbang serta aman dalam jumlah dan komposisi yang cukup (Beragam, Bergizi, Seimbang dan Aman) yang melalui dari masing-masing rumah tangga. Program Percepatan Penganekaragaman Konsumsi Pangan (P2KP) yang dilakukan antara lain melalui kegiatan optimalisasi pemanfaatan pekarangan, yang dapat menjadi sumber pangan keluarga, bukan saja terbatas pada tanaman sebagai sumber 
karbohidrat, vitamin dan mineral, melainkan juga pada ternak dan ikan sebagai sumber protein. Keberhasilan Penganekaragaman Konsumsi Pangan tercermin dari indikator outcome-nya berupa "makin beragam dan berimbangnya pola konsumsi pangan penduduk yang diukur dengan skor Pola Pangan Harapan (PPH) yang semakin meningkat, dan menurunya konsumsi beras 1,5\% per tahun". Untuk mengetahui sejauh mana perubahan pola konsumsi pangan masyarakat, perlu dilakukan pemantauan konsumsi pangan di wilayah P2KP.

Pelaksanaan PP Nomor 68 Tahun 2002 tentang Ketahanan Pangan, oleh Pemerintah Kabupaten/Kota dan/atau Pemerintah Desa merupakan tanggung jawab terhadap penyelenggaraan ketahanan pangan di wilayahnya masingmasing, dengan memperhatikan pedoman, norma, standar, dan kriteria yang ditetapkan oleh Pemerintah Pusat. Pemerintah Kabupaten/kota dan/atau Pemerintah Desa mendorong keikutsertaan masyarakat dalam penyelenggaraan ketahanan pangan. Oleh karena itu, pemerintah dan masyarakat bersama-sama mempunyai kewajiban untuk membangun ketahanan pangan.

Dengan demikian Dinas Ketahanan Pangan Kabupaten Subang merupakan salah satu yang bertanggung jawab mencapai keberhasilan imlplementasi kebijakan Ketahanan Pangan dan Gizi di Kabupaten Subang salah satu ciri terwujudnya ketahanan pangan di rumah tangga adalah terpenuhinnya pangan yang cukup, beragam, bergizi, berimbang dan aman serta terjangkau bagi setiap warga. Tingkat konumsi pangan penduduk yang cukup dan beragam menunjukan keberhasilan penyelenggaraan urusan wajib bidang ketahanan pangan oleh pemerintah kota atau kabupaten. Untuk mewujudkan Ketahanan Pangan dan Gizi di Kabupaten Subang agar terpenuhinnya pangan yang cukup, beragam, bergizi, berimbang dan aman serta terjangkau bagi setiap warga, tidak terlepas dibuatnya suatu kebijakan publik. Menurut Dye dalam Winarno (2016: 19) mengatakan bahwa kebijakan publik adalah apapun yang dipilih oleh pemerintah untuk dilakukan dan tidak dilakukan. Salah satu kebijakan yang berkaitan dengan penyelenggaraan Ketahanan Pangan dan Gizi adalah kebijakan tentang Ketahanan Pangan dan Gizi sesuai dengan Peraturan Pemerintah Republik Indonesia Nomor 17 Tahun 2015. Pada pasal 1 ayat 1 PP Nomor 17 Tahun 2015 yang dimaksud dengan Ketahanan Pangan dan Gizi kondisi terpenuhinya kebutuhan pangan dan gizi bagi negara sampai dengan perseorangan, yang tercermin dari ketersediannya pangan yang cukup, baik jumlah maupun mutunya, aman, beragam, memenuhi kecukupan gizi, merata dan terjangkau serta tidak bertentangan dengan agama, keyakinan, dan budaya masyarakat, untuk mewujudkan status gizi yang baik agar dapat hidup sehat, aktif, dan produktif secara berkelanjutan. Di dalamnya mencakup ruang lingkup cadangan pangan, penganekaragaman pangan dan perbaikan gizi masyarakat, kesiapsiagaan dan penanggulangan krisis pangan, distribusi, perdagangan dan bantuan pangan.

Salah satu wilayah yang telah melaksanakan kebijakan ketahanan pangan dan gizi adalah Kabupaten Subang. Dinas Ketahanan Pangan Kabupaten Subang sebagai implementor beranggung jawab dalam hal pelaksanaan 
ketahanan pangan dan gizi dalam menjalankan tugas ketahanan pangan dan gizi belum tercapai sesuai harapan sebagaimana ciri-ciri capaian keberhasilan ketahanan pangan dan gizi. Namun berdasarkan hasil penjajagan dan wawancara awal (pra survei) yang penulis lakukan, ditemukan beberapa perbedaan antara pelaksanaan kebijakan dengan kebijakan ketahanan pangan dan gizi di Kabupaten Subang sebagaimana mestinya. Dalam pelaksanaan pelatihan pengolahan hasil pangan lokal dalam kegiatan penganekaragaman konsumsi pangan baru dilaksanakan pada tahun 2018 sedangkan kebijakan tentang ketahanan pangan dan gizi telah di sahkan semenjak 2015. Pada tahun 2018 pelaksanaan kegiatan penganekaragaman konsumsi pangan di Kabupaten Subang dilaksanakan pada Kecamatan Purwadadi, Pagaden, Cibogo, Jalancagak, dan cipunagara. Sedangkan pada tahun 2019 yaitu di Kecamatan Dawuan, Pamanukan, Ciasem, dan Cibogo. Pemilihan Kecamatan tersebut dilakukan sesuai dengan hasil Musrembang. Pelaksanaan kegiatan ini dilaksanakan di desa, tetapi dalam satu kecamatan tidak semua Desa/Kelurahan mendapatkan sosialisasi tentang penganekaragaman konsumsi pangan hanya Desa/Kelurahan yang mau saja untuk mendapatkan sosialisasi pelatihan pengolahan hasil pangan lokal dalam kegiatan percepatan penganekaragaman konsumsi pangan. Sehingga kejelasan dan sasaran kebijakan tidak dapat dilihat secara spesifik, diakhir program tidak dapat diketahui keberhasilan atau kegagalan dari kebijakan yang telah dijalankan.

Dalam segi sumber daya, di Kabupaten Subang belum mempunyai cadangan pangan pemerintah daerah berdasarkan PP Nomor 17 Tahun 2015 pada bagian kedua dijelaskan bahwa cadangan pangan pemerintah daerah terdiri dari:

1. Cadangan Pangan Pemerintah Desa,

2. Cadangan Pangan Pemerintah Kabupaten/Kota, dan

3. Cadangan Pangan Pemerintah Provinsi

Pada tanggal 25 Juli 2017 Dinas Ketahanan Pangan Kabupaten Subang telah mengusulkan anggaran cadangan pangan pemerintah daerah Kabupaten Subang tahun 2018 sebesar Rp. 540.000.000,- untuk pengadaan beras cadangan pangan pemerintah daerah sebanyak 60 ton dan sampai sekarang anggaran tersebut tidak teralisasi. Maka dari itu di Kabupaten subang tidak terdapat cadangan pangan pemerintah daerah baik berupa beras ataupun gudang penyimpanan.

Tabel 1.

Situasi Konsumsi Pangan di Kabupaten Subang Tahun 2017

\begin{tabular}{|c|l|c|c|c|c|c|}
\hline $\begin{array}{c}\mathbf{N} \\
\mathbf{0}\end{array}$ & $\begin{array}{c}\text { Kelompok } \\
\text { Pangan }\end{array}$ & $\begin{array}{c}\text { Energi } \\
\text { (Kkal/kap/hr } \\
\mathbf{)}\end{array}$ & $\begin{array}{c}\text { \% } \\
\text { AKE }\end{array}$ & $\begin{array}{c}\text { Protein } \\
(\mathbf{g r} / \mathbf{k a p} / \mathbf{h r} \\
\mathbf{)}\end{array}$ & $\begin{array}{c}\text { \% } \\
\mathbf{A K P *}\end{array}$ & $\begin{array}{c}\text { Sko } \\
\mathbf{r} \\
\mathbf{P P H}\end{array}$ \\
\hline 1. & Padi-padian & $1.481,20$ & 74,1 & 33,6 & 64,5 & 25,0 \\
\hline 2. & Umbi-umbian & 47,2 & 2,4 & 0,4 & 0,8 & 1,2 \\
\hline
\end{tabular}




\begin{tabular}{|c|l|c|c|c|c|c|}
3. & Pangan Hewani & 250,4 & 12,5 & 24,2 & 46,6 & 24,0 \\
\hline 4. & $\begin{array}{l}\text { Minyak dan } \\
\text { Lemak }\end{array}$ & 221,1 & 11,1 & 0,0 & 0,0 & 5,0 \\
\hline 5. & $\begin{array}{l}\text { Buah/Biji } \\
\text { Berminyak }\end{array}$ & 11,4 & 0,6 & 0,3 & 0,5 & 0,3 \\
\hline 6. & $\begin{array}{l}\text { Kacang- } \\
\text { kacangan }\end{array}$ & 53,8 & 2,7 & 5,6 & 10,7 & 5,4 \\
\hline 7. & Gula & 67,2 & 3,4 & 0,1 & 0,2 & 1,7 \\
\hline 8. & Sayur dan Buah & 88,2 & 4,4 & 2,9 & 5,7 & 22,1 \\
\hline 9. & Lain-lain & 38,1 & 1,9 & 1,1 & 2,2 & 0,0 \\
\hline & Total & $2.258,52$ & 112,9 & 68,22 & 131,2 & 84,6 \\
\hline
\end{tabular}

Sumber: Laporan akhir pemantauan dan analisis pola pangan harapan Kabupaten Subang tahun 2018

*) Angka kecukupan Energi (AKE): $2.000 \mathrm{kkal} / \mathrm{kap} / \mathrm{hari}$

**) Angka Kecukupan Protein (AKP): 52 gr/kap/hari

Hasil pada tabel diatas menunjukan bahwa konsumsi pangan penduduk tidak proporsional pada setiap kelompok pangan. Hasil perhitungan menunjukan bahwa konsumsi padi-padian mencapai 74,1\% AKE, pangan hewani 21,1\% AKE, minyak dan lemak 11,1\% AKE, sementara itu umbiumbian, buah/biji berminyak, kacang-kacangan, gula serta sayur dan buah masih rendah. Hal ini diketahui dari skor AKE pangan tersebut lebih rendah dari skor maksimal. Pencapaian skor PPH kabupaten Subang pada tahun 2017 terlihat menurun dibandingkan dengan tahun 2016 (tahun 2016 skor PPH 86,2 dan pada tahun 2017 skor PPH 84,6).

Berdasarkan hasil penelitian pada Dinas Ketahanan Pangan Kabupaten Subang maka ditemukan pula masalah yang berkaitan dengan implementasi kebijakan Ketahanan Pangan dan Gizi belum optimal yang meliputi dari indikator dibawah ini:

1. Kejelasan dan sasaran kebijakan tidak dapat dilihat secara spesifik, diakhir program tidak dapat diketahui keberhasilan atau kegagalan dari kebijakan yang telah dijalankan. Karena dilihat dari pelaksanaan pelatihan pengolahan hasil pangan lokal dalam kegiatan penganekaragaman konsumsi pangan baru dilaksanakan pada tahun 2018 sedangkan kebijakan ketahanan pangan dan gizi telah di sahkan pada tahun 2015. Pada 2018 kegiatan tersebut dilaksanakan di Kecamatan Purwadadi, Pagaden, Cibogo, Jalancagak, dan cipunagara. Sedangkan pada tahun 2019 yaitu di Kecamatan Dawuan, Pamanukan, Ciasem, dan Cibogo. Dalam satu kecamatan tidak semua Desa/Kelurahan mendapatkan sosialisasi, hanya Desa/Kelurahan yang mau saja untuk mendapatkan sosialisasi pelatihan pengolahan hasil pangan lokal dalam kegiatan penganekaragaman konsumsi pangan.

2. Pada tahun 2017 Dinas Ketahanan Pangan Kabupaten Subang telah mengusulkan anggaran cadangan pangan pemerintah daerah kabupaten 
subang tahun 2018 sebesar Rp. 540.000.000,- untuk pengadaan beras cadangan pangan pemerintah daerah sebanyak 60 Ton dan sampai sekarang anggaran tersebut tidak teralisasi. Cadangan pangan pemerintah daerah yaitu berfungsi untuk memberikan bantuan kepada daerah yang terkena bencana, keluarga rawan pangan, menstabilkan harga beras, dan sebagai persediaan pangan atau bufer stok di pemerintah berdasarkan PP Nomor 17 tahun 2015 bagian ke dua.

3. Dinas Ketahanan Pangan, Dinas Pertanian, Dinas Kesehatan, Dinas Perikanan, Dinas Peternakan dan Kesehatan Hewan, Dinas Pemberdayaan Masyarakat dan Desa, Dinas Sosial, Dinas Koperasi, UMKM, Perdagangan dan Perindustrian Kabupaten Subang dan Badan Perencanaan Penelitian dan Pengembangan Daerah.

Komitmen dari pelaksana kebijakan sendiri masih setengah-setengah. Memang dalam kegiatan rapat pengembangan sistem kewaspadaan pangan dan gizi (SKPG) Dinas Ketahanan Pangan Kabupaten Subang dan Stakholder menghadirinya tetapi dalam melaksanakan kebijakan tersebut tidak dijalankan dengan komitmen yang tinggi hal tersebut dapat dilihat dari skor PPH pada tahun 2017 yaitu 84,6. Skor PPH tersebut masih dibawah skor PPH sesuai dengan SPM maupun PPH ideal.

Berdasarkan latar belakang yang telah diuraikan di atas, guna memudahkan dalam pemecahan masalah, maka penulis mengidentifikasikan pokok masalah yang menjadi fokus dalam penelitian ini adalah bagaimana proses implementasi Kebijakan Ketahanan Pangan dan Gizi di Kabupaten Subang. Adapu kerangka teoritiknya sebagai berikut:

Kebijakan publik memiliki makna yang luas. Ada yang menyebut kebijakan sebagai sebuah aturan, terkadang kebijakan diartikan sebagai suatu ketetapan/keputusan, dan bahkan kebijakan dapat diartikan pula kepada apa yang dilakukan oleh pemerintah. Kebijakan publik merupakan sebuah keputusan yang ditetapkan atas musyawarah legislatif (pembuatan kebijakan). Dalam prakteknya, suatu kebijakan publik dijadikan sebagai landasan dasar dalam proses penyelenggaraan pemerintah, seperti halnya di indonesia. Berkaca dari kebijakan yang menjadi dasar penyelenggaraan roda pemerintahan, artinya kebijakan tidak hanya sekedar wacana di atas kertas atau sebagai sebuah ketetapan saja, akan tetapi lebih dari itu. Dalam kajian kebijakan publik bahwa sehubungan dengan implementasi kebijakan, dimana implementasi ini merupakan salah satu proses yang ada pada siklus kebijakan. Perlu disadari pula bahwa suatu kebijakan sangat perlu untuk di implementasikan agar tujuan-tujuan dari kebijakan bisa diaplikasikan secara nyata dan program-program yang telah dirumuskan di dalamnya dapat diterapkan sesuai sasarannya. Termasuk juga dalam kebijakan mengenai ketahanan pangan dan gizi.

Dalam hal Peraturan Pemerintah Republik Indonesia Nomor 17 Tahun 2015 tentang ketahanan pangan dan gizi. Kebijakan ini bertujuan untuk memenuhi kebutuhan pangan dan gizi bagi negara sampai dengan 
perseorangan yang tercermin dari tersedianya pangan yang cukup baik jumlah maupun mutunya, aman, beragam, memenuhi kecukupan gizi, merata dan terjangkau.

Dari gagasan tersebut, penulis berkeinginan mengetahui bagaimana proses atau upaya-upaya pemerintah dalam pelaksanaan kebijakan ketahanan pangan dan gizi di Kabupaten Subang. Karena setelah melakukan penjajagan masih terdapat masalah terkait pelaksanaan kebijakan ini. Alasan pemilihan teori implementasi kebijakan dari Van Meter dan Van Horn yaitu teori ini dianggap lebih relevan dengan permasalahan yang telah dijelaskan pada latar belakang. Van Meter dan Van Horn menawarkan suatu model yang mencakup enam variabel yang membentuk kaitan (linkage) antara kebijakan dan kinerja (Perfoemance). Variabel-variabel tersebut dijelaskan oleh Van Meter dan Van Horn dalam Winarno (2016: 142-150) sebagai berikut: Ukuran-Ukuran Dasar dan Tujuan-Tujuan Kebiakan, Sumber-sumber Kebijakan, Komunikasi Antar Organisasi dan Kegiatan-kegiatan Pelaksanaan, dan kecenderungan pelaksana (Implementors)

\section{Kerangka Teori}

\section{Kebijakan Publik}

Kebijakan Secara etimologi, istilah kebijakan berasal dari Bahasa Inggris "policy". Akan tetapi, kebanyakan orang berpandangan bahwa istilah kebijakan senantiasa disamakan dengan istilah kebijaksanaan. Padahal apabila dicermati berdasarkan tata bahasa, istilah kebijaksaan berasal dari kata "wisdom". Peneliti berpandangan bahwa istilah kebijakan berbeda dengan istilah kebijaksanaan. Hal ini didasarkan pada pertimbangan bahwa pengertian kebijaksanaan memerlukan pertimbangan-pertimbangan yang lebih lanjut, sedangkan kebijakan mencakup peraturan-peraturan yang ada didalamnya termasuk konteks politik. Pendapat Anderson yang dikutip oleh (Wahab 2012:14-15), merumuskan kebijaksanaan sebagai langkah tindakan yang secara sengaja dilakukan oleh seorang aktor atau sejumlah aktor berkenaan dengan adanya masalah atau persoalan tertentu yang sedang dihadapi (Hikmawan, 2017b). Oleh karena itu, kebijaksanaan menurut Anderson merupakan langkah tindakan yang disengaja dilakukan oleh aktor yang berkenaan dengan adanya masalah yang sedang dihadapi.

Kebijakan publik adalah faktor yang me-leverage kehidupan bersama. Dalam teori Preto, sebagaimana dikutif Nugroho (2008) dalam Rusli (2015: 35) dikatakan bahwa kebijakan publik adalah $20 \%$ yang menyebabkan terjadinya yang $80 \%$. Tidak berlebihan jika dinyatakan bahwa kebijakan publik merupakan faktor kritikal bagi kemajuan atau kemunduran suatu bangsa (Hikmawan, 2017a). Sehebat apapun demokrasi jika sistem politik nya tidak mampu mengembangkan kebijakan publik yang unggul, tidak ada gunanya. Kebijakan publik adalah output yang nyata dari setiap sistem politik. Kebijakan publik adalah bentuk riil dari politik. 
Pada prosesnya, pembuatan kebijakan publik merupakan proses yang kompleks karena melibatkan banyak proses maupun variabel yang harus dikaji. Hal tersebut oleh beberapa ahli disusun kedalam beberapa tahap. Adapun tahapan-tahapan kebijakan publik menurut Winarno (2016: 30-32) adalah sebagai berikut:

1. Tahap Formulasi Kebijakan

Masalah yang telah masuk kedalam agenda kebijakan kemudian dibahas oleh para pembuat kebijakan. Masalah-masalah tadi di definisikan untuk kemudian dicari pemecahan masalah terbaik. Pemecahan masalah tersebut berasal dari berbagai alternatif atau pilihan-pilihan kebijakan (policy alternativesl policy options) yang ada." untuk mengusulkan pemecahan masalah terbaik.

2. Tahap Adopsi Kebijakan

Dari sekian banyak alternatif kebijakan yang ditawarkan oleh para perumus kebijakan, pada akhirnya salah satu dari kebijakan tersebut diadopsi dengan dukungan dari mayoritas legilatif. Konsensus antara direktur lembaga atau keputusan peradilan.

3. Tahap Implementasi Kebijakan

Suatu program kebijakan hanya akan mejadi catatan-catatan elite, jika program tersebut tidak diimplementasikan. Oleh karena itu, keputusan program kebijakan yang telah diambil sebagai alternatif pemecahan masalah harus diimplementasikan, yakni dilakukan oleh badan-badan administrasi maupun agen-agen pemerintah di tingkat bawah.

4. Tahap Evaluasi Kebijakan

Pada tahap ini kebijakan yang telah dijalankan akan dinilai dan dievaluasi untuk melihat sejauh mana kebijakan yang dibuat telah mampu memecahkan masalah. Kebijakan publik pada dasarnya dibuat untuk meraih dampak yang diinginkan. Dalam hal ini, memecahkan masalah yang dihadapi masyarakat. Oleh karena itu, ditentukan lah ukuran-ukuran atau kriteria-kriteria yang menjadi dasar untuk menilai apakah kebijakan publik telah meraih dampak yang diinginkan.

\section{Konsep Implementasi Kebijakan}

Implementasi kebijakan dipandang dalam pengertian yang luas merupakan tahap dari proses kebijakan segera setelah penetapan undangundang. Implementasi dipandang luas mempunyai makna pelaksanaan undang-undang dimana berbagai aktor, organisasi, prosedur, dan teknik bekerja bersama-sama untuk menjalankan kebijakan dalam upaya untuk meraih tujuan-tujuan kebijakan atau program-program (Hikmawan, 2017b). Implementasi pada sisi lain merupakan fenomena yang kompleks yang mungkin dapat dipahami sebagai suatu proses, suatu keluaran (output) maupun sebagai suatu dampak (outcome).

Jones (2000: 20) dalam bukunya "An Introduction to the study of Public Policy" dalam (Rusli, 2015: 88), mengemukakan aktivitas implementasi terdapat 3 (tiga) macam, yaitu: 
1. Organization, aktivitas pengorganisasian merupakan suatu upaya menetapkan dan menata kembali sumber daya (resources), unit-unit (units) dan metode-metode (methods) yang mengarah pada upaya mewujudkan (merealisasikan kebijakan menjadi hasil/output) sesuai dengan apa yang tujuan dan sasaran kebijakan. (the establishment or rearrangement of resources, units, and methods for putting a policy into effect).

2. Interpretation, aktivitas interprestasi merupakan aktivitas interprestasi (penjelasan) subtansi dari suatu kebijakan 241onsenbahasa yang lebih opersional dan mudah dipahami, sehingga subtansi kebijakan dapat dilaksanakan dan diterima oleh para pelaku dan sasaran kebijakan (The translation of language (often contained in a statue) into acceptable and feasible plans and directives).

3. Application, aktivitas aplikasi merupakan aktivitas penyediaan pelayanan secara rutin, pembayaran atau lainnya sesuai dengan tujuan dan sasaran kebijakan yang ada.

Beberapa pengertian mengenai implementasi itu dimaknai sebagai sesuatu bermuara pada aktivitas, aksi, tindakaan, atau adanya mekanisme suatu sistem. Dimana kegiatan implemntasi bukan sekedar aktivitas, tetapi suatu kegiatan yang terencana dan untuk mencapai tujuan kegiatan. Artinya, kegiatan implementasi itu bukan sekedar aktivitas, tetapi suatu kegiatan yang terencana dan dilakukan secara sungguh-sungguh berdasarkan acuan norma tertentu untuk mencapai tujuan kegiatan. Dari semua definisi yang ada, Riant Nugroho D (2003: 156) dalam (Rusli, 2015: 90) menyimpulkan dengan sebuah kalimat sederhana bahwa implementasi kebijakan pada prinsipnya adalah cara agar sebuah kebijakan dapat mencapai tujuannya. Dengan pemaknaan seperti itu maka studi implemntasi merupakan suatu kajian mengenai studi kebijakan yang mengarah pada proses pelaksanaan dari suatu kebijakan. Secara etimologi, kata implementasi berasal dari bahasa Inggris "to implement", yang artinya pelaksanaan dan penerapan. Bebeapa diantara para ahli mendefinisikan tentang implementasi kebijakan: Daniel Mazmanian dan Paul Sabatier sebagaimana dikutip Agustino (2008: 139) dalam (Rusli, 2015: 91) mendefinisikan impelentasi kebijakan sebagai: "pelaksanaan keputusan kebijakan dasar, biasanya dalam bentuk undang-undang, namun dapat pula berbentuk perintah-perintah atau keputusan-keputusan eksekutif yang penting atau keputusan badan peradilan. Lazimnya keputusan tersebut mengidentifikasikan masalah yang ingin diatasi, menyebutkan secara tegas tujuan atau sasaran yang ingin dicapai, dan berbagai cara untuk menstrukturkan atau mengatur proses implementasinya." Sedangkan Van Metter dan Van Horn dalam (Rusli, 2015: 91), mendefinisikan implementasi kebijakan, sebagai: “Tindakan-tindakan yang dilakukan baik oleh individuindividu atau pejabat-pejabat atau kelompok-kelompok pemerintah atau swasta yang diarahkan pada pencapaiannya tujuan-tujuan yang telah digariskan dalam keputusan kebijaksanaan badan-badan ini melaksanakan tugas-tugas pemerintaha yang berdampak pada warga". Gordon dalam (Pasolong, 2017:68) mendefinisikan implementasi kebijakan sebagai: "Implementasi berkenaan 
dengan berbagai kegiatan yang diarahkan pada realisasi program. Dalam hal ini administrator mengatur cara untuk mengorganisir, menginterpretasikan dan menerapkan kebijakan yang telah diseleksi (Widiyanto, Hikmawan, \& Riswanda, 2019).

Bila dikaitkan dengan bermacam-macam kasus dan konteks kebijakan, maka diantara semua model tersebut memiliki kelebihan dan kekurangan jika digunakan sebagai acuan untuk melihat bagaimana kebijakan publik itu dilaksanakan dalam mencapai tujuannya.

A. Model Edward III

George C. Edwards III dalam Rusli (2015: 100-104) melalui model implementasi kebijakan publiknya yang diberi nama Dirtect and Indirect impact on implementation ia menyebutkan empat faktor yang mempengaruhi pelaksanaan atau implementasi kebijkan publik. Keempat faktor tersebut adalah:

1. Communication (Komuniasi)

Syarat pertama agar pelaksanaan kebijakan itu efektif, kebijakan ini harus disampaikan/ diketahui oleh orang-orang yang diserahi tanggung jawab untuk melaksanakannya dengan jelas. Dalam konteks implementasi kebijakan dalam menurut Edwards III (1980: 17), dalam komunikasi terdapat 3 aspek yang penting, yaitu:

a. Transmisi, sebelum pejabat publik mengimplementasikan suatu keputusan, ia harus menyadari bahwa suatu keputusan telah dibuat dan suatu perintah untuk pelaksanaannya telah dikeluarkan.

b. Kejelasan, jika kebijakan-kebijakan akan diimplementasikan sebagaimana yang diinginkan, maka petunjuk-petunjuk pelaksanaan tidak hanya harus diterima tetapi juga harus jelas (clear).

c. Konsistensi, dari beberapa faktor yang menghasilkan komunikasi yang tidak jelas juga menyebabkan komunikasi yang tidak konsisten yaitu (Edwards III, 1980: 42): 1. Kompleksitas kebijakan publlik, 2. Kesulitankesulitan untuk memulai program baru, 3. Banyaknya tujuan dari berbagai kebijakan (Multiple objectives of many policies).

2. Resources (Sumberaya)

Syarat berjalannya suatu organisasi adalah kepemilikan terhadap sumberdaya (resources). Implementasi kebijakan akan tidak efektif apabila implementor kekurangan sumber daya yang penting untuk melaksanakan kebijakan. Pentingnya sumber daya mendapatkan perhatian penuh dari Edwards yang menyatakan bahwa kurangnya sumber daya akan berakibat ketidakefektifan penerapan kebijakan. Tanpa sumber daya kebijakan tinggal di kertas menjadi dokumen saja.

3. Disposition (Sikap Pelaksana)

Disposisi adalah watak dan karakteristik yang dimiliki oleh implementor, seperti komitmen, kejujuran, sifat demokratis (Mulyadi, 2015: 68). Apabila implementor memiliki disposisi yang baik, maka dia dapat menjalankan kebijakan dengan baik seperti apa yang diinginkan oleh pembuat kebijakan, maka proses implementasi kebijakan menjadi tidak efektif. 


\section{Bureaucratic Structures (Struktur Birokasi)}

struktur organisasi yang bertugas mengimplementasikan kebijakan memiliki pengaruh yang signifikan terhadap implementasi kebijakan. Salah satu dari aspek struktur yang penting dari setiap organisasi adalah adanya prosedur organisasi yang standar (Standar Operating Procedures SOP). SOP menjadi pedoman bagi setiap implementor dalam bertindak. Struktur organisasi yang terlalu panjang akan cenderung melemahkan pengawasan dan menimbulkan redtape, yakni prosedur birokrasi yang rumit dan kompleks. Ini pada gilirannya menyebabkan aktivitas organisasi tidak fleksibel.

B. Model Van Meter dan Van Horn

Van Meter dan Van Horn menawarkan suatu model yang mencakup enam variabel yang membentuk kaitan (linkage) antara kebijakan dan kinerja (Perfoemance). Variabel-variabel tersebut dijelaskan oleh Van Meter dan Van Horn dalam Winarno (2016: 142-150) sebagai berikut:

1. Ukuran-Ukuran Dasar dan Tujuan-Tujuan Kebiakan

Variabel ini di dasarkan pada kepentingan utama terhadap faktor-faktor yang menentukan kinerja kebijakan. Indikator-indikator kinerja ini menilai sejauh mana ukuran-ukuran dasar dan tujuan-tujuan kebijakan telah direalisasikan. Ukuran-ukuran dasar dan tujuan-tujuan berguna dalam menguraikan tujuan-tujuan keputusan kebijakan encakupsecara menyeluruh, di samping itu, ukuran-ukuran dasar dan tujuan-tujuan merupakan bukti itu sendiri dan dapat diukur dengan mudah dalam beberapa kasus.

\section{Sumber-sumber Kebijakan}

Yang perlu mendapatkan perhatian dalam proses implementasi kebijakan adalah sumber-sumber yang tersedia. Sumber-sumber layak mendapatkan perhatian karena menunjang keberhasilan implementasi kebijakan. Sumbersumber yang dimaksud mencakup dana atau perangsang (incetive) lain yang mendorong dan melancarkan implementasi yang efektif. Dalam praktek implementasi kebijakan, kita sering kali mendengar para pejabat maupun pelaksana mengatakan bahwa kita tidak mempunyai cukup dana untuk membiayai program-program yang telah direncancanakan. Dengan demikian, dalam beberapa kasus besar kecilnya dana akan menjadi faktor yang menentukan keberhasilan implementasi kebijkan.

3. Komunikasi Antar Organisasi dan Kegiatan-kegiatan Pelaksanaan

Komunikasi di dalam antara antar organisasi-organisasi merupakan suatu proses yang kompleks dan sulit. Dalam meneruskan pesan-pesan ke bawah dalam suatu organisasi ke organisasi lainnya, para komunikator dapat menyimpangkannya atau menyebarluaskannya, baik secara sengaja ataupun tidak sengaja. Lebih dari itu, jika sumber-sumber informasi berbeda memberikan interprestasi-interprestasi yang bertentangan, para pelaksana akan menghadapi pelaksana akan menghadapi kesulitan yang lebih besar untuk melaksanakan maksud-maksud kebijakan.

4. Karakteristik Badan Pelaksana

Dalam melihat karakteristik badan-badan pelaksana, seperti dinyataka Van Meter dan Van Horn, maka ini tidak lepas dari struktur birokrasi. 
Struktur birokrasi diartikan sebagai karakteristik-karakteristik, normanorma dan pola-pola dalam badan-badan aksekutif yang mempunyai hubungan baik potensial maupun hanya dengan apa yang mereka miliki dengan menjalankan kebijakan. Komponen dari model ini terdiri dari ciriciri struktur formal dari organisasi-organisasi dan atribut-atribut yang tidak formal dari personal mereka.

5. Kondisi-Kondisi Ekonomi, Sosial, dan Politik

Dampak kondisi-kondisi ekonomi, sosial, dan politik pada kebijakan publik merupakan pusat perhatian yang besar selama dasawarsa yang lalu. Para peminat perbandingan politik dan kebijakan publik secara khusus tertarik dalam mengidentifikasikan pengaruh variabel-variabel lingkungan pada hasil-hasil kebijakan.

6. Kecenderungan Pelaksana (Implementors)

Menurut Van Meter dan Van Horn dalam (Winarno, 2016: 149) ada tiga unsur tanggapan pelaksana yang mungkin mempengaruhi kemampuan dan keinginan mereka untuk melaksanakan kebijakan, yakni: kognisi (komprehensi, pemahaman) tentang kebijakan, macam tanggapan terhadapnya (penerimaan, netralitas, penolakan) dan intensitas tanggapan itu. Arah kecenderungan-kecenderungan pelaksana terhadap ukuranukuran dasar dan tujuan-tujuan juga merupakan suatu hal yang sangat penting.

\section{Kebijakan Ketahanan Pangan dan Gizi}

Pangan adalah segala sesuatu yang berasal dari sumber hayati, produk pertanian, perkebunan, kehutanan, perikanan, peternakan, perairan, dan air, baik yang diolah maupun tidak diolah yang diperuntukkan sebagai makanan atau minuman bagi konsumsi manusia, termasuk bahan tambahan pangan, bahan baku pangan, dan bahan lainnya yang digunakan dalam penyiapan, pengolahan, dan/atau pembuatan makanan atau minuman (Undang-Undang Republik Indonesia 18 Tahun 2012).

Ketersediaan pangan dapat diwujudkan melalui proses kedaulatan pangan dan penganekaragaman pangan. Pemenuhan kebutuhan pangan merupakan hak negara dan bangsa yang secara mandiri menentukan kebijakan. Pangan yang menjamin hak atas pangan bagi rakyat dan yang memberikan hak bagi masyarakat untuk menentukan sistem pangan yang sesuai dengan potensi sumber daya lokal. Berikut disajikan beberapa definisi ketahanan pangan menurut Hanani (2009) dalam (Purwangsih, 2011: 5):

1. Undang-Undang Pangan No.7 Tahun 1996 yang diperbaharui dalam Undnag-Undang Republik Indonesia Nomor 18 Tahun 2012 kondisi terpenuhinya kebutuhan pangan bagi rumah tangga yang tercermin dari ketersedianya pangan secara cukup, baik dari jumlah maupun mutunya, aman, merata dan terjangkau.

2. Mercy Corps (2007): keadaan ketika semua orang pada setiap saat mempunyai akses fisik, sosial, dan ekonomi terhadap kecukupan pangan, 
aman dan bergizi untuk kebutuhan gizi sesuai dengan seleranya untuk hidup produktif dan sehat.

Strategi yang diterapkan dalam rangka keberhasilan pembangunan ketahanan pangan (Hanafie, 2010: 275) sebagai berikut:

1. Pemberdayaan ketahanan pangan masyarakat.

2. Pengembangan sistem dan usaha agrobisnis.

3. Mewujudkan kebersamaan antara masyarakat sebagai pelaksana pemerintah sebagai fasilitator.

4. Menumbuhkan ketahanan pangan pada tingkat rumah tangga, mengelola produksi pangan dengan baik dalam memenuhi kebutuhan konsumsi keluarga, dan mampu menyalurkan kelebihan produksi pangan untuk memperoleh harga yang wajar. Kesadaran masyarakat akan pentingnya penganekaragaman pangan dengan mutu pangan yang dikonsumsi harus semakin meningkat dalam mewujudkan ketahanan pangan pada tingkat rumah tangga.

5. Pemantapan koordinasi dan sinkronisasi pihak-pihak terkait dalam perencanaan, kebijakan, pembinaan, dan pengendalian.

Menurut I Dewa Nyoman Suparisa dkk (2002:17-18) dalam (Almatsir, 2004: 8) mejelaskan bahwa gizi adalah suatu proses organisme menggunakan makanan yang dikonsumsi secara normal melalui proses degesti, absorpsi, transportasi, penyimpanan, metabolisme dan pengeluaran zat yang tidak digunakan untuk mempertahankan kehidupan, pertumbuhan, dan fungsi normal dari organ-organ serta menghasilkan energi.

Menurut Sunita Almatsier (2004:11) dalam bukunya prinsip dasar ilmu gizi, zat-zat gizi yang dapat memberikan energi adalah karbohidrat, lemak, dan protein, oksidasi zat-zat gizi ini menghasilkan gizi energi yang diperlukan untuk melakukan kegiatan atau aktivitas. Ketiga zat gizi termasuk zat organik yang mengandung karbon yang dibakar, jumlah zat gizi yang paling banyak terdapat dalam pangan dan disebut juga zat pembakar.

Sedangkan pengertian status gizi menurut Sunita Almatsir (2004:3) keadaan tubuh sebagai akibat konsumsi makanan dan penggunaan zat-zat gizi. Dibedakan antara status gizi buruk, kurang, baik, dan lebih. Oleh karena keterkaitan gizi dengan berbagai faktor seperti pertanian, sosial, ekonomi dan budaya maka perbaikan gizi masyarakat dilakukan dengan pendekatan sistem yang lazim dinamakan Sistem Pangan dan Gizi. Sistem pangan dan gizi mempunyai tujuan meningkatkan dan mempertahankan status gizi masyarakat dalam keadaan optimal. Menurut Sunita Almatsir (2004: 12-13) sistem pangan dan gizi mempunyai empat komponen yaitu:

1. Penyediaan pangan, upaya mencapai status gizi masyarakat yang baik atau optimal dimulai dengan penyediaan pangan yang cukup. Penyediaan pangan yang cukup diperoleh melalui produksi pangan dalam negeri melalui upaya pertanian dalam menghasilkan bahan makanan pokok, lauk pauk, sayur-mayur, dan buah-buahan.

2. Distribusi pangan, agar sampai kepada masyarakat luas dalam keadaan baik, distribusi pangan perlu memperhatikan aspek transportasi, 
penyimpanan, pengolahan, pengemasan, dan pemasaran. Tujuannya adalah untuk pangan yang disediakan sampai di masyarakat secara merata, dalam keadaan baik, tidak banyak terbuang dan dengan harga yang dapat terjangkau.

3. Konsumsi makanan, konsumsi makanan oleh masyarakat atau oleh keluarga bergantung pada jumlah dan jenis pangan yang dibeli, pemasakan, distribusi dalam keluarga, dan kebiasaan makan secara perorangan.

4. Utilitasi atau penggunaan makanan, penggunaan makanan oleh tubuh bergantung pada pencernaan dan penyerapan serta metabolisme zat gizi. Hal ini tergantung pada kebersihan lingkungan dan ada tidaknya penyakit yang berpengaruh terhadap penggunaan zat-zat gizi oleh tubuh.

Menurut PP Nomor 17 Tahun 2015 Ketahanan pangan dan gizi adalah kondisi terpenuhinya kebutuhan pangan dan gizi bagi negara samapai dengan perseorangan, yang tercermin dari ketersediannya pangan yang cukup, baik jumlah maupun mutunya, aman, beragam, memenuhi kecukupan gizi, merata dan terjangkau serta tidak bertentangan dengan agama, keyakinan, dan budaya masyarakat, untuk mewujudkan status gizi yang baik agar dapat hidup sehat, aktif, dan produktif secara berkelanjutan.

Ruang lingkup Peraturan Pemerintah ini meliputi:

1. Cadangan Pangan Pemerintah dan Cadangan Pangan Pemerintah Daerah.

2. Penganekaragaman Pangan dan Perbaikan Gizi Masyarakat

3. Kesiapsiagaan Krisis Pangan dan Penanggulangan Krisis Pangan

4. Distribusi Pangan, Perdagangan Pangan, dan Bantuan Pangan.

5. Pengawasan

6. Sistem Informasi Pangan dan Gizi

7. Peran Serta Masyarakat.

\section{Metode Penelitian}

Dalam penelitian ini peneliti menggunakan metode penelitian Naturalistik/Kualitatif dengan tingkat eksplanasi Deskriptif. Metode penelitian Naturalitik/kualitatif adalah metode penelitian yang digunakan untuk meneliti pada kondisi obyek alamiah (sebagai lawannya adalah eksperimen), dimana peneliti adalah sebagai instrumen kunci, teknik pengumpulan data dilakukan secara triangulasi (gabungan), analisis data bersifat induktif, dan hasil penelitian kualitatif lebih menekankan makna daripada generalisasi Sugiono (2017: 9). Sedangkan tingkat eksplanasi atau yang disebut tingkat kejelasannya, dalam hal ini bagaimana variabel-variabel yang diteliti itu dapat menjelaskan objek yang diteliti melalui data yang terkumpul (Pasolong, 2013:71), dalam penelitian ini menggunakan penelitian Deskriptif yaitu penyelidikan yang dilakukan terhadap variabel mandiri atau satu variabel mandiri atau satu variabel, tanpa membuat perbandingan, atau menghubungkan dengan variabel yang lain (Pasolong, 2013:72). 


\section{Penentuan Informan}

Dalam memilih informan penelitian kualitatif, peneliti menggunakan teknik non probability sampling, suatu teknik pengambilan sampel yang tidak didasarkan pada rumusan statistik, tetapi lebih pada pertimbangan subyektif penelitian dengan didasarkan jangkauan dan kedalaman masalah yang diteliti. bidang mesin.

Oleh karena itu penelitian yang akan dilakukan mengacu pada teknik tersebut, maka penulis mengambil sampel informan sebagai berikut:

1. Kepala Dinas Ketahanan Pangan Kabupaten Subang, karena sebagai ketua pelaksana Ketahanan Pangan dan Gizi yang dianggap memahami tentang Peraturan Pemerintah Nomor 17 Tahun 2015.

2. Kepala Bidang Penganekaragaman Konsumsi dan Keamanan Pangan, karena dianggap mengetahui informasi mengenai penganekaragaman konsumsi dan keamanan pangan terkait pelaksanaan kebijakan ketahanan pangan dan gizi.

3. Kepala Bidang Ketersediaan dan Kerawanan Pangan, karena dianggap mengetahui mengenai informasi pelaksanaan kebijakan ketahanan pangan dan gizi.

4. Kepala Bidang Distribusi dan Cadangan Pangan, karena dianggap mengetahui informasi mengenai distribusi dan cadangan pangan yang ada di Kabupaten Subang dalam rangka pelaksanaan kebijakan ketahanan pangan dan gizi.

5. Ketua Seksi Cadangan Pangan, karena sebagai ketua dianggap mengetahui tentang Cadangan Pangan Pemerintah Daerah yang ada di Kabupaten Subang.

6. Masyarakat Kabupaten Subang, karena masyarakat adalah orang yang secara langsung menjadi kelompok sasaran Kebijakan Ketahanan Pangan dan Gizi.

7. Kelompok yang berpartisipasi dalam kegiatan Kebijakan Ketahanan Pangan dan Gizi di Kabupaten Subang, dianggap mengetahui sejauh mana proses pelaksanaan kebijakan Ketahanan Pangan dan Gizi.

8. Stakeholder pelaksana Kebijakan Ketahanan Pangan dan Gizi yang terdiri dari Dinas Pertanian, Dinas Kesehatan, Dinas Perikanan, Dinas Peternakan dan Kesehatan Hewan, Dinas Pemberdayaan Masyarakat dan Desa, Dinas Sosial, Dinas Koperasi, UMKM, Perdagangan dan Perindustrian, dan Badan Perencanaan, Pembangunan, Penelitian dan Pengembangan Daerah. Karena dianggap sebagai implementor kebijakan mengetahui sejauh mana pelaksanaan Kebijakan Ketahanan Pangan dan Gizi di Kabupaten Subang.

\subsection{Instrumen Penelitian}

Cresswell (2013:261) mejelaskan bahwa dalam penelitian kualitatif, penelitian sebagai instrumen kunci (Researcher as key instrument). Hal ini dilakukan karena, jika memanfaatkan alat yang bukan manusia dan mempersiapkan dirinya terlebih dahulu sebagai yang lazim digunakan dalam penelitian klasik, maka sangat tidak mungkin untuk mengadakan penyesuaian 
terhadap kenyataan-kenyataan yang ada dilapangan. Selain itu hanya manusia sebagai alat yang dapat berhubungan dengan responden atau obyek lainnya.

1.2 Teknik Pengumpulan Data

Pada penelitian ini penulis menggunakan data dengan menggunakan dua jenis data, yaitu data primer dan data sekunder.

Untuk memperoleh pemahaman yang mendalam terhadap suatu obyek penelitian yang diamati, penelitian ini menggunakan teknik pengumpulan data melalui wawancara, observasi dan studi dokumentasi.

Validitas data menurut Sugiyono (2017: 268) "validitas merupakan ketepatan antara data yang sesungguhnya terjadi pada objek penelitian dengan data yang dilaporkan oleh peneliti". Dengan demikian data yang valid adalah data yang tidak berbeda antara data yang dilaporkan oleh peneliti dengan data yang sesungguhnya terjadi pada objek penelitian. Analisis data yang dilakukan adalah pengolalaan data kualitatif yang menjelaskan tentang eksistensi sebuah permasalahan dengan menggambarkan secara sistematis seluruh elemen yang bersifat kualitatif yang berkaitan dengan permasalahan. Analisis data yang digunakan dalam penelitian ini yaitu: reduksi data, penyajian data, dan kesimpulan.

\section{Hasil dan Diskusi}

\section{Kabupaten Subang Dalam Data}

Kabupaten Subang sebagai salah satu Kabupaten dikawasan utara Provinsi Jawa Barat meliputi luas wilayah 2.051,76 $\mathrm{km}^{2} \quad(79,219 \mathrm{sq} \mathrm{mi})$ atau $6.34 \%$ dari luas Provinsi Jawa Barat. Wilayah ini terletak di antara $107^{\circ} 31^{\prime}$ sampai dengan $107^{\circ} 54^{\prime}$ Bujur Timur dan $6^{\circ} 49^{\prime}$ Lintang Selatan. Secara administratif kabupaten subang terbagi atas 253 Desa dan Kelurahan yang tergabung dalam 30 Kecamatan. Berdasarkan Peraturan Daerah Kabupaten Subang Nomor 3 Tahun 2007 tentang Pembentukan Wilayah Kerja Camat, Jumlah Kecamatan bertambah menjadi 30 Kecamatan.

Wilayah Kabupaten Subang terbagi menjadi 3 bagian wilayah, yakni wilayah selatan, wilayah tengah dan wilayah utara. Bagian selatan terdiri atas dataran tinggi/pegunungan, bagian tengah berupa dataran, sedangkan bagian utara merupakan dataran rendah yang mengarah langsung ke Laut Jawa. Batas-batas wilayah administratif Kabupaten Subang adalah di sebelah selatan berbatasan dengan Kabupaten Bandung Barat, di sebelah barat dengan Kabupaten Purwakarta dan Karawang, di sebelah timur dengan Kabupaten Sumedang dan Indramayu dan Laut Jawa yang menjadi batas di sebelah utara.

Suatu kebijakan publik tidak terlepas dari tahapan implementasi kebijakan. Tahapan ini merupakan salah satu bagian terpenting dari siklus kebijakan publik pada umumnya. Pengimplementasian kebijakan memberikan makna kebijakan lebih dinamis dan realistis daripada sekedar sebagai sebuah ketetapan yang lebih bersifat statis.

Menurut Van Metter dan Van Horn dalam Rusli (2015: 91), mendefinisiskan impelemntasi kebijakan sebagai tindakan-tindakan yang 
dilakukan baik oleh individu-individu atau pejabat-pejabat atau kelompokkelompok pemerintah atau swasta yang diarahkan pada pencapaiannya tujuantujuan yang telah digariskan dalam keptusan kebijaksanaan. Jika suatu kebijakan telah direncanakan dengan sangat baik mungkin juga akan mengalami kegagalan, apabila kebijakan tersebut kurang diimplementasikan dengan baik oleh para pelaksana kebijakan.

Implementasi kebijakan publik yang dimaksud dalam penelitian ini adalah implementasi dari Peraturan Pemerintah Nomor 17 Tahun 2015 tentang Ketahanan Pangan dan Gizi. Di dalamnya mengatur tentang Cadangan Pangan Pemerintah dan Cadangan Pemerintah Daerah, Penganekaragaman Pangan dan Perbaikan Gizi Masyarakat, Kesiapsiagaan Krisis Pangan dan Penanggulangan Krisis Pangan, Distribusi Pangan, Perdagangan Pangan, dan Bantuan Pangan, Pengawasan, Sistem Informasi Pangan dan Gizi, dan Peran Serta Masyarakat.

Untuk mengukur bagaimana implementasi kebijakan Ketahanan Pangan dan Gizi yang dijalankan di Kabupaten Subang. Menurut Van Meter dan Van Horn dalam Winarno (2016:142-150) menyatakan bahwa ada beberapa variabel yang mempengaruhi keberhasilan implementasi kebijakan seperti yang dikaji dibawah ini, yakni:

\section{Ukuran-ukuran Dasar atau Tujuan-tujuan Kebijakan}

Menurut Van Meter dan Van Horn dalam implementasi, ukuran dan tujuan kebijakan harus realistis dengan sosio kultur yang ada di level pelaksana kebijakan itu sendiri. Ketika ukuran dan tujuan kebijakan terlalu berat untuk dilaksanakan di level masyarakat, maka sulit merealisasikan kebijakan publik hingga titik yang dapat dikatakan berhasil. Perlu ada indikator-indikator pencapaian target dapat menilai sejauh mana ukuran-ukuran dan dasar tujuan kebijakan telah direalisasikan. Kejelasan dan sasaran kebijakan harus dapat dilihat secara spesifik sehingga di akhir program dapat diketahui keberhasilan atau kegagalan dari kebijakan atau program yang dijalankan.Berikut adalah hasil wawancara penulis dengan Sekertaris Dinas Ketahanan Pangan Kabupaten Subang yang mewakili untuk pertanyaan Kepala Dinas, mengenai ukuran-ukuran dasar dan tujuan-tujuan kebijakan Ketahanan Pangan dan Gizi di Kabupaten Subang sebagai berikut: "di Ketahanan Pangan ada Bidangbidang, Bidang Ketersediaan dan Kerawanan Pangan, Bidang Distribusi dan Cadangan Pangan, dan Bidang Penganekaragaman Konsumsi dan Keamanan Pangan. Gizi itu tidak terlepas dari pangan, kalau pangannya tidak mencukupi maka gizi nya akan kurang. Makanya di Ketahana Pangan ada Bidang Penganekaragaman Konsumsi Di dalamnya berkaitan dengan konsumsi jadi bagaimana masyarakat Kabupaten Subang itu mengkonsumsi pangannya yang Beragam, Bergizi, Aman dan Seimbang (B2SA). Di Ketahanan Pangan ada kegiatan seperti Intervensi Gizi kepada masyarakat di bidang kerawanan pangan dengan memberikan bantuan berupa sembako kepada masyarakat yang dibawah garis kemiskinan tetapi karena anggaran terbatas jadi tidak semua dapat terfasilitasi." Berdasarkan penyataan di atas bahwa tujuan dari 
Kebijakan Ketahanan Pangan dan Gizi adalah agar masyarakat yang ada di Kabupaten Subang itu mengkonsumsi pangan dengan memeperhatikan B2SA (Beragam, Bergizi, Seimbang, dan Aman) agar terhindar dari daerah rawan pangan. Tetapi masih ada yang kurang yaitu karena terbatasnya anggaran sehingga tidak bisa memfasilitasi semua kelompok sasaran yang ada di Kabupaten Subang. Sedangkan Kabid Distribusi dan Cadangan Pangan Dinas Ketahanan Pangan Kabupaten Subang menyatakan sebagai berikut:"Tujuan dari kebijakan itu kan maksudnya yang dari pusat atau provinsi kalau untuk kabupaten yang menjadi acuan atau pedoman untuk kerja kita supaya dapat memberikan pelayanan khususnya di Bidang Ketahanan Pangan dan Gizi. Sasaran dari kebijakan sudah tepat karena sudah ada yang biasa mengelola bantuan tersebut, mislanya di bidang ini ada program PUPM, program LPM, dan program LDPM". Pernyataan dari Kabid Distribusi dan Cadangan pangan menjelaskan bahwa tujuan dari kebijakan ketahanan pangan dan gizi yaitu pelayanan yang diberikan kepada masyarakat khususnya dalam bidang ketahanan pangan dan gizi. Kelompok sasaran dari kebijakan ini akan diberikan program berupa PUPM, LPM, dan LDPM.

Hasil wawancara dengan Kasi Ketersediaan Pangan: “Ketahanan Pangan dan gizi itu adalah terpenuhinya kebutuhan pangan masyarakat dan tercukupinya gizi sampai dengan perseorangan. Sasaran dalam kebijkan ini dirasa sudah tepat sasaran karena ditunjukan kepada masyarakat yang mengalami rawan pangan."Berikut adalah hasil wawancara dengan Kasi Sumberdaya Pangan: "Tujuan kebijakan ketahanan pangan dan gizi itu adalah agar tersedianya pangan masyarakat baik dari protein nabati, hewaninya. Tersedianya pangan sesuai dengan kebutuhan dan tercukupinya gizi masyarakat sehingga tidak ada lagi daerah yang rawan pangan. Ada juga hambatan tentang ketahanan pangan di Kabupaten Subang yaitu banyak lahan pertanian yang beralih fungsi." Berikut adalah hasil wawancara dengan Kasi Rawan Pangan: "ketahanan pangan dan gizi itu adalah memanfaatkan hasil pangan yang di hasilkan agar tidak ada kerawanan pangan dan disamping pemanfaatan itu harus dibarengi dengan gizi. Dalam bidang ini untuk memenuhi kebutuhan konsumsi hewani di bidang ini ada pemberian bantuan berupa pemberian domba, dan ayam yang bertujuan agar dapat dikelola oleh masyarakat". Selain Dinas Ketahanan Kabupaten Subang sebagai implementor dari kebijakan ketahanan pangan dan gizi di Kabupaten Subang ada instansi terkait yang sama-sama berperan dalam pelaksanaan kebijakan tersebut. Salah satu stakeholder nya yaitu Dinas Pertanian, berikut adalah hasil wawancara dengan Kasi Pengelolaan Pemasaran Hasil Tanaman Perkebunan mengenai standar dan ukuran kebijakan yaitu: "Dinas Pertanian itu salah satu untuk meningkatkan poduksi terutama beras untuk penunjang makanan pokok bagi masyarakat agar meningkatkan ketahanan pangan. untuk kelompok sasaran kita ke petani salah satunya membantu pemberian benih padi dan umbiumbian." Melihat hasil wawancara di atas, Dinas Pertanian sebagai salah stakeholder yaitu membantu untuk peningkatan produksi beras yang ada di 
Kabupaten Subang dengan memberikan bantuan berupa benih padi dan umbiumbian kepada para petani Subang.

Melihat hasil wawancara dengan Kasi Promdalur dan PDN jawabannya berbeda dengan Stakholder di atas. Dinas KUPP mengontrol harga rata-rata HET yang ada di lapangan (Pasar) dan hasil dari harga tersebut dilaporkan kepada instansi terkait. Berikut adalah hasil wawancara dengan Staf Fungsional KPPM Dinas Pemberdayaan Masyarakat dan Desa Kabupaten Subang menganai standar dan ukuran kebijakan yaitu: “untuk tujuan kebijakan ketahanan pangan dan gizi saya tidak tahu karena di sini itu lembaga dari posyandu untuk pelatihan kader-kader dan bantuan kepada posyandu yang ada di Desa/Kelurahan." Hasil wawancara dengan Staf Fungsional KUPP menyebutkan Dinas Pemberdayaan Masyarakat Desa memberikan pelatihanpelatihan kepada kader-kader posyandu yang ada di Desa/ Kelurahan. Berikut adalah hasil wawancara dengan Kasi Penanganan Fakir Miskin Dinas Sosial Kabupaten Subang mengenai standar dan ukuran kebijakan yaitu: "untuk Dinas Sosial hanya menyajikan data kemiskinan saja, dan memberikan bantuan kepada masyarakat yang ada di program kita seperti BNT, sasaran dari kebijakan ini saya rasa sudah tepat karena data orang miskin juga meminta langsung kepada Kecamatan."

Berbeda dengan hasil wawancara dengan masyarakat yang penulis jadi informan berkenaan dengan standar dan ukuran kebijakan: "untuk program kebijakan ketahanan pangan dan gizi saya tidak tahu tapi saya merasakan ada bantuan dari pemerintah berupa pembagian sembako yang didalamnya berisi beras, gula, minyak, dan kebutuhan pokok lainnya diberikan dalam satu tahun hanya satu kali. Dan setiap ada bantuan juga saya tahunya dari Pemerintah Desa langsung." Melihat hasil wawancara di atas masyarakat merasakan bantuan dari pihak Pemerintah berupa pemberian sembako yang diberikan langsung kepada masyarakat dalam satu tahun hanya satu kali. Berdasarkan hasil wawancara di atas dengan pihak Dinas Ketahanan Pangan dan instansi terkait (stakeholders) bahwa ada kesamaan jawaban mengenai tujuan dari Kebijakan Ketahanan Pangan dan Gizi yaitu untuk pemenuhan kebutuhan pangan dengan memperhatikan asupan gizi yang seimbang. Kelompok sasaran dari kebijakan ini yaitu kepada masyarakat yang mengalami rawan pangan, masyarakat miskin, dan stunting. Sedangkan jawaban dari kelompok yang berpartisipasi dan masyarakat yang menjadi kelompok sasaran ada yang menyebutkan mengetahui program dari Kebijakan Ketahanan Pangan dan Gizi dan ada juga yang tidak mengetahuinya.

\section{Sumber-sumber Kebijakan}

Keberhasilan proses implementasi kebijakan sangat tergantung dari pemanfaatan sumber-sumber kebijakan yang tersedia. Manusia merupakan salah satu sumber daya yang terpenting dalam keberhasilan proses implementasi. Tahap-tahap tertentu dari keseluruhan proses implementasi menuntut adanya sumber daya manusia yang berkualitas sesuai dengan pekerjaan yang diisyaratkan oleh kebijakan yang telah ditetapkan secara 
politik. Di luar sumber daya manusia, ada sumber daya lain yang perlu diperhatikan juga ialah sumber daya finansial. Ketika sumber daya manusia yang kompeten dan kapabel telah tersedia tetapi kucuran dana melalui anggaran tidak tersedia, maka akan menimbulkan masalah untuk merealisasikan apa yang menjadi tujuan kebijakan dalam (Agustino, 2016: 134).

Hasil wawancara penulis dengan Sekertaris Dinas Ketahanan Pangan Kabupaten Subang yang mewakili untuk pertanyaan Kepala Dinas, mengenai sumber-sumber kebijakan baik itu sumberdaya manusia ataupun non manusia dalam pelaksanaan kebijakan Ketahanan Pangan dan Gizi di Kabupaten Subang sebagai berikut: "Sarana dan prasarana yang dimiliki Dinas Ketahanan Pangan belum lengkap karena yang pertama keterbatasan anggaran, kedua karena Dinas Ketahanan Pangan baru berjalan 2 tahun. Jadi dukungan sumber daya anggaran dari Pemerintah atau APBD II belum begitu mencukupi. Misalkan kita mau menyentuh masyarakat yang kekurangan gizi berapa besarannya, kemarin saja untuk memfasilitasi 1 Desa 75 orang ini ada 3 Desa berarti baru 225 dari 3 Desa 3 Kecamatan. Sedangkan dalam pelaksanaan masih banyak orang yang masih belum difasilitasi, artinya sarana dan prasarana belum memadai. Dan dari segi Sumber Daya Manusia yang dimiliki Dinas Ketahanan Pangan jumlah personalnya hanya 37 orang seharusnya di Dinas Ketahanan Pangan harus ada Sarjana yang khusus menangani Ketahanan Pangan dan Fungsional Ketahanan Pangan, memang disini banyak Sarjana Pertanian seharusnya ada diklat yang khusus mengenai Ketahanan Pangan. Jangankan ahli-ahli pangan tenaga administrasi saja masih kurang. Sehingga di Dinas Ketahanan Pangan belum ada orang-orang yang ahli di bidangnya."

Menyimak dari hasil wawancara di atas menyatakan bahwa sarana dan prasarana yang ada masih kurang karena kendaraan yang digunakan untuk memantau dan mengevaluasi kegiatan di daerah masih terbatas. Berikut adalah hasil wawancara dengan Kabid Penganekaragaman Konsumsi dan Keamanan Pangan Dinas Ketahanan Pangan Kabupaten Subang tentang sumber daya anggaran sebagai berikut: "Dilihat dari sumber anggaran sangat jauh untuk memfasilitasi satu kabupaten yang terdiri dari 30 Kecamatan, paling yang terfasilitasi hanya 6 kecamatan. Dan SDA juga harus banyak pelatihanpelatihan, belajar tentang perencanaan." Pendapat di atas menyatakan bahwa sumber daya anggaran masih kurang karena yang terfasilitasi hanya 6 Kecamatan, dan segi SDA pun harus diberikan pelatihan-pelatihan. Berikut adalah hasil wawancara dengan Kasi Ketersediaan Pangan: "dalam bidang ini sumber daya anggaran yang ada sangat kurang, karena di Kabupaten Subang itu ada 10 Daerah yang rawan pangan tapi pihak Dinas hanya bisa memfasilitasi 3 Desa dari 3 Kecamatan yang mengalami rawan pangan. 3 Kecamatan itu terdiri dari Kecamatan Cipendeuy, Kecamatan Binong, dan Kecamatan Pusakanagara"

Dibawah ini adalah tabel skor aspek akses pangan yang menunjukan daerah aman, wapada, dan rentan atau daerah rawan pangan di Kabupaten Subang. 
Tabel 2.

Skor Aspek Akses Pangan

Bulan Januari 2019

\begin{tabular}{|c|l|l|l|}
\hline \multicolumn{5}{|c|}{ Skor Aspek Akses Pangan } \\
\hline No & \multicolumn{1}{|c|}{ Aman } & \multicolumn{1}{|c|}{ Waspada } & \multicolumn{1}{|c|}{ Rentan } \\
\hline 1 & Blanakan & Binong & Ciater \\
\hline 2 & Ciasem & Cikaum & Cibogo \\
\hline 3 & Dawuan & Cipunagara & Cijambe \\
\hline 4 & Kalijati & Compreng & Cisalak \\
\hline 5 & Pabuaran & Legonkulon & Jalancagak \\
\hline 6 & Patokbeusi & Pagaden & Kasomalang \\
\hline 7 & Cipendeuy & Pagaden Barat & Sagalaherang \\
\hline 8 & Purwadadi & Pamanukan & Serangpanjang \\
\hline 9 & Sukasari & Pusakajaya & Subang \\
\hline 10 & & Pusakanagara & Tanjungsiang \\
\hline 11 & & Tambakdahan & \\
\hline & & & 10 \\
\hline Jumlah & 9 & 11 & 10 \\
\hline
\end{tabular}

Sumber:Dinas Ketahanan Pangan Kabupaten Subang

Menyimak hasil wawancara diatas menyebutkan bahwa fasilitas yang ada sudah memadai dan sumber daya manusia sudah memiliki kualitas dan kompetensi sesuai dengan bidangnya. Berikut adalah hasil wawancara dari masyarakat mengenai sumber-sumber kebijakan yaitu: "dalam pembagian sembako itu dalam satu RT hanya diberi beberapa orang saja dan masih banyak yang berhak mendapatkan tapi tidak menerima, dan dalam satu tahun hanya diberi satu kali bantuan. Terlihat jelas hasil wawancara di atas menyebutkan bahwa fasilitas yang ada tidak memadai karena tidak bisa memefasilitasi semua masyarakat yang ada di Desa tersebut yang berhak medapatkan bantuan perbaikan ketahanan pangan dan gizi.

Menyimak hasil wawancara penulis dengan Sekertaris, Kabid, dan Kasi Dinas Ketahanan Pangan, instansi terkait, kelompok yang berpartisipasi dan masyarakat. Maka penulis berasumsi bahwa implementasi Kebijakan Ketahanan Pangan dan Gizi di Kabupaten Subang dilihat dari indikator sumber-sumber kebijakan belum optimal hal ini dilihat dari:

1. Sarana dan prasarana yang ada di Dinas Ketahanan Pangan masih kurang seperti kendaraan Dinas untuk memantau 30 Kecamatan, dan tidak memiliki Cadangan Pangan Pemerintah Daerah.

2. Sumber daya anggaran yang dimiliki masih relatif kecil sehingga hanya bisa memfasilitasi masyarakat dalam satu tahun itu 6 atau 3 Kecamatan, dan dari satu Kecamatan hanya 1 Desa yang diberikan bantuan.

3. Sumber daya manusia yang dimiliki Dinas Ketahanan Pangan belum memiliki orang-orang yang ahli dalam bidang ketahanan pangan dan dari 
sejak berdiri pada tahun 2017 tidak pernah dilaksanakan diklat untuk aparatur.

\section{Komunikasi Antar Organisasi dan Kegiatan-kegiatan Pelaksana}

Menurut Van Meter dan Van Horn dalam (Agustino, 2016:135) koordinasi merupakan mekanisme sekaligus syarat utama menentukan keberhasilan pelaksana kebijakan. Semakin baik koordinasi dan komunikasi di antara pihakpihak yang terlibat dalam suatu proses implementasi, maka asumsinya kesalahan-kesalahan akan sangat kecil terjadi dan begitu pula sebaliknya. Komunikasi ini harus ditetapkan sebagai acuan, misalnya sering dilaksanakan rapat-rapat rutin secara berkala dalam tempat dan waktu yang telah ditetapkan, agar dapat mendukung komunikasi organisasi antar instansi yang berkaitan dalam program/ kebijakan dengan kelompok sasaran yang mampu memahami serta bertanggungjawab atas program yang dilaksanakan. Berikut adalah hasil wawancara penulis dengan Sekertaris Dinas Ketahanan Pangan Kabupaten Subang yang mewakili untuk pertanyaan Kepala Dinas mengenai hubungan dengan instansi terkait dalam pelaksanaan kebijakan Ketahanan Pangan dan Gizi di Kabupaten Subang sebagai berikut: "Komunikasi yang dilakukan belum optimal karena masih ada daerah tertentu yang masih kekurangan gizi di antaranya ada yang stunting atau kurang gizi akibat belum maksimal dalam penyampaian informasi. Dinas Ketahanan Pangan melakukan koordinasi dengan Dinas Kesehatan dari segi gizi dan dari segi pangan itu dari Dinas Pertanian, Dinas Perikanan, Dinas Peternakan dan Kesehatan Hewan. Melihat kutipan wawancara di atas bahwa komunikasi antar badan pelaksana belum berjalan optimal dikarnakan masih ada daerah-daerah yang mengalami rawan pangan dan Dinas Ketahanan Pangan sendiri melakukan koordinasi dengan instansi terkait untuk pengimplementasian kebijakan Ketahanan Pangan dan Gizi. Hasil wawaancara dengan Kasi Ketersediaan Pangan: "Dalam bidang ini kan ada kegiatan SKPG maka dalam satu bulan sekali di adakan rapat dengan instansi terkait. Koordinasi yang kami lakukan sebagai pelaksana dengan instansi terkait berjalan sangat baik karena untuk membantu jalannya kegiatan yang ada dibidang ini dan menangani kerawanan pangan yang ada di Kabupaten Subang." masalah orang yang miskin ada berapa yang mendapat bantuan, Dinas KUPP."

Berdasarkan hasil wawancara diatas menyatakan bahwa koordinasi yang dilakukan dengan instansi terkait sudah berjalan dengan baik dengan membantu kelancaran kegiatan berdasarkan bidangnya masing-masing. Hasil wawancara dengan Kasi Cadangan Pangan: "komunikasi yang dilakukan dengan antar badan pelaksana yang ada di daerah belum optimal karena cakupannya terlalu luas dan Dinas Ketahanan Pangan tidak mempunyai UPTD atau Penyuluh yang ada di Kecamatan. sehingga ketika ada kegiatan Dinas terjun langsung ke lapangan. Koordinasi yang dilakukan dengan Desa dilaksanakan dengan baik misalkan mengadakan rapat mengenai kebutuhan masyarakat desa contohnya mereka membutuhkan gudang pangan nanti di usulkan ke Kecamatan dari Kecamatan ditampung di Kabupaten. 


\section{Karakteristik Badan-badan Pelaksana}

Karakteristik agen pelaksana merupakan sikap komitmen dari pelaksana terhadap kebijkan atau program yang harus dilaksanakan karena setiap kebijakan membutuhkan pelaksana-pelaksana memiliki komitmen yang tinggi agar mampu mencapai tujuan kebijakan diharapkan seperti kognisi, arahan tanggapan pelaksana dan respon dari pelaksana (Anggara, 2014-225). Menurut Van Meter dan Van Horn Para peminat politik birokrasi telah mengidentifikasikan banyak karakteristik badan-badan administratif yang telah memengaruhi kebijakan mereka. Maka hal ini tidak terlepas dari struktur birokrasi diartikan sebagai karakteristik-karakteristik, norma-norma dan polapola hubungan yang terjadi berulang-ulang dengan badan-badan yang mempunyai hubungan baik potensial maupun nyata dengan apa mereka miliki dengan menjalanka kebijakan dalam (Winarno, 2016: 147-148). Berikut adalah hasil wawancara penulis dengan Sekertaris Dinas Ketahanan Pangan Kabupaten Subang yang mewakili untuk pertanyaan Kepala Dinas mengenai karakteristik badan-badan pelaksana dalam pelaksanaan kebijakan Ketahanan Pangan dan Gizi di Kabupaten Subang sebagai berikut: "Dinas Ketahanan Pangan sebagai pelaksana mempunyai norma-norma yang tertuang dalam tufoksi pelaksana, dan sudah menjalankan norma tersebut apalagi jika dikaitkan dengan disiplin pegawai. Para pelaksana komitmen dalam melaksanakan tugas karena apa yang sudah disepakati atau sesuai dengan aturan harus dipatuhi. Contohnya jika ada kegiatan di bidangnya masingmasing pelaksana ikut serta dalam kegiatan tersebut."

Menyimak hasil wawancara yang penulis lakukan dengan para stakholder menyebutkan bahwa struktur organisasi yang ada sudah berjalan dengan baik sesuai dengan tufoksi dan dapat dilihat dari terealisasinya program-program yang telah direncanakan serta mengacu pada norma yang berlaku dengan memegang komitmen yang tinggi dalam menjalankan tanggung jawab. Berikut adalah hasil wawancara dengan Organisasi Masyarakat Pemuda Pancasila mengenai karakteristik badan pelaksana: "mereka tahu apa yang harus dikerjakan tapi mereka tidak mau tahu, contohnya ketika ada masalah dimasyarakat mereka tidak bisa mengantisifasinya. Mereka hanya bertanggung jawab atas pekerjaannya tapi tidak bertanggung jawab terhadap dampaknya". Berdasarkan hasil wawancara diatas para implementor itu hanya mementingkan input nya saja tidak memperhatikan dampak yang akan dirasakan langsung oleh masyarakat yang menjadi kelompok sasaran dari kebijakan.

\section{Kondisi-kondisi Ekonomi, Sosial, dan Politik}

Hal selanjutnya yang juga diperhatikan guna menilai kinerja implementasi kebijakan publik dalam perspektif Van Meter dan Van Horn dalam (Agustino, 2016:136) adalah sejauh mana lingkungan eksternal mendorong keberhasilan kebijkan publik yang telah ditetapkan. Lingkungan yang dimaksud termasuk lingkungan sosial, ekonomi, dan politik. Dan 
lingkungan yang tidak kondusif dapat menjadi biang keladi dari kegagalan kinerja implementasi kebijakan. Oleh sebab itu, upaya untuk mengimplementasikan kebijakan harus pula memperhatikan kekondusifan kondisi lingkungan eksternal. Berikut adalah hasil wawancara penulis dengan Sekertaris Dinas Ketahanan Pangan Kabupaten Subang yang mewakili untuk pertanyaan Kepala Dinas mengenai kondisi ekonomi, sosial dan politik dalam pelaksanaan kebijakan Ketahanan Pangan dan Gizi di Kabupaten Subang sebagai berikut: "dari segi ekonomi di Kabupaten Subang yang dinamakan masyrakat miskin dari segi data itu banyak dan kondisi ekonomi pun akan berpengaruh karena jika masih banyak masyarakat miskin maka jelas pasti masih ada masyarakat yang gizi buruk, dan daerah-daerah yang mengalami rawan pangan." Dari kutipan wawancara di atas menyatakan bahwa keadaan ekonomi yang ada di masyarakat masih berpenghasilan rendah, sehingga keadaan ekonomi akan mempengaruhi implementasi kebijakan. Berikut adalah hasil wawancara dengan Kabid Distribusi dan Cadangan Pangan Dinas Ketahanan Pangan Kabupaten Subang sebagai berikut: "Dari segi politik ketahanan pangan itu seperti ketahanan Negara, jika ketahanan pangan terganggu maka ketahanan negara pun akan rusak, sehingga banyak orangorang asing yang masuk ke negara kita untuk melemahkan negara. Begitu pun di Kabupaten Subang secara normatif di Kabupaten Subang relatif aman karena sebagai salah satu lumbung padi. Namun pada pelaksanaannya masih perlu adanya cadangan pangan pemerintah daerah sehingga lebih kondusif ketika ada suasana yang tidak di inginkan."

Hasil wawancara dengan Organisasi Masyarakat Laskar Indonesia mengenai kondisi sosial, ekonomi, dan politi yaitu : "ya faktor ekonomi juga menjadi salah satu faktor penghambat, karena ketika ekonomi masyarakat semakin rendah maka daya beli untuk asupan pangan yang bergizi akan diabaikan. Masyarakat harus mendukung kebijakan ketahanan pangan dan gizi karena untuk menciptakan sumberdaya manusia Subang yang unggul dan pihak Pemerintah setempat pun mendung dengan program-program dari kebijakan ini. Berdasarkan kutipan wawancara di atas keduanya menyebutkan bahwa faktor ekonomi merupakan faktor penghambat dalam implementasi Kebijakan Ketahanan Pangan dan Gizi, karena ketika faktor ekonomi yang ada dimasyrakat rendah maka daya beli untuk asupan gizi yang seimbang akan terbaikan. Berikut adalah hasil wawancara dengan masyarakat Kabupaten Subang mengenai kondisi sosial, ekonomim, dan politik yaitu: "ya kondisi ekonomi menjadi salah satu faktor penghambat karena masyarakat yang ada di desa ini masih berpendapan rendah. masyarakat sangat mendukung dalam Kebijakan Ketahanan Pangan dan Gizi karena dapat membantu ketahanan pangan perorangan melalui program KRPL dan ada dukungan juga dari Pemerintah Desa." Berikut adalah hasil wawancara dengan masyrakat mengenai kondisi sosial, ekonomi dan politik yaitu: "memang keadaan ekonomi masyarakat menjadi faktor penghambat harena disini kebanyakan buruh dan masih berpendapan rendah. Masyarakat sangat mendukung kebijakan Ketahanan Pangan dan Gizi karena dampaknya juga akan dirasakan 
langsung oleh masyarakat." Mengutip hasil dua wawancara di atas menyebutkan bahwa faktor ekonomi menjadi penghambat dalam implementasi kebijakan karena mayoritas dari mereka masih berpendapatan rendah dan masyarakat pun mendukung dari Kebijakan Ketahanan Pangan dan Gizi.

Meyimak hasil wawancara penulis dengan Dinas Ketahanan Pangan, instansi terkait, kelompok yang berpartisipasi, dan masyarakat, maka penulis berasumsi bahwa implementasi Kebijakan Ketahanan Pangan dan Gizi di Kabupaten Subang dilihat dari indikator kondisi sosial, ekonomi, dan politik belum optimal hal ini dilihat dari:

1. Kondisi ekonomi masyarakat yang menjadi kelompok sasaran itu rata-rata berpendapatan rendah, kondisi sosial masyarakat kurang berpartisipasi ketika ada kegiatan dan tidak bisa memanfaatkan apa yang diberi oleh pemerintah.

2. Kondisi ekonomomi berpengaruh karena masyarakat rata-rata berpendapatan rendah maka mereka tidak memperhatikan asupan gizi dikarkanakan tidak mampu untuk membelinya.

\section{Kecenderungan Pelaksana}

Kecenderungan pelaksana atau disposisi adalah watak dan karakteristik yang dimiliki implementor apabila implementor memiliki disposisi yang baik, maka dia akan mejalankan kebijakan dengan baik seperti apa yang diinginkan oleh pembuat kebijakan. Ketika implementor memiliki sikap atau perspektif yang berbeda dengan pembuat kebijakan, maka proses implementasi kebijakan juga menjadi tidak efektif. Sikap penerimaan atau penolakan dari pelaksana akan mempengaruhi keberhasilan dan kinerja dari kebijakan publik. Hal ini sangat mungkin terjadi karena kebijakan yang dilaksanakan bukan hasil dari formulasi warga setempat tetapi kebijakan yang akan implementor laksanakan adalah kebijakan dari atas (top down) yang sangat mungkin dalam pengambilan keputusan tidak pernah mengetahui kebutuhan, keinginan, atau permasalahan yang warga ingin selesaikan. Berikut adalah hasil wawancara penulis dengan Sekertaris Dinas Ketahanan Pangan Kabupaten Subang yang mewakili untuk pertanyaan Kepala Dinas mengenai kecenderungan pelaksana dalam pelaksanaan kebijakan Ketahanan Pangan dan Gizi di Kabupaten Subang sebagai berikut: "saya memahami tentang kebijakan ketahanan pangan dan gizi yang namanya ketahanan pangan masyarakat yang ada dikabupaten subang sudah tidak ada lagi kerawanan pangan, artinya kebutuhan-kebutuhan itu sudah ada yang terpenuhi. Jika pangannya sudah terpenuhi gizi nya juga pasti terpenuhi. Pangan itu tidak hanya beras tapi karbohidrat, protein, kalsium. Jika masyarakat gizi nya sudah terpenuhi semua maka ketahanan pangan kuat jika tidak maka kerawanan pangan." Berikut adalah hasil wawancara dengan Kabid Distribusi dan Cadangan Pangan Dinas Ketahanan Pangan Kabupaten Subang sebagai berikut: "saya memahami tentang kebijakan ketahanan pangan dan gizi, paling tidak saya tau apa yang harus saya pahami tentang ketentuan atau kebijakan yang berlaku. Saya ingin ada inovasi kreasi baru terhadap kebijakan baru yang akan dikeluarkan saya ingin sekali ada 
Perda tentang Cadangan Pangan Pemerintah Daerah Kabupaten Subang." Melihat dari dua kutipan wawancara di atas menunjukan bahwa para implementor memahami tentang kebijakan ketahanan pangan dan gizi dan menunjukan respon yang sangat baik dalam implementasi kebijakan. Berikut adalah hasil wawancara dengan Kabid Penganekaragaman Konsumsi dan Keamanan Pangan Dinas Ketahanan Pangan Kabupaten Subang sebagai berikut: "saya tidak begitu 100\% memahami tentang kebijakan ketahanan pangan dan gizi, tetapi ada panduan yang dipelajari sambil berjalan. Respon saya tentang kebijakan ini sangat bagus sekali karena kalau ditumbuh kembangkan kegiatan yang dilaksanakan oleh Dinas Ketahanan Pangan kita berharap masyarakat tidak ada gizi buruk dan stunting."

Menyimak hasil wawancara di atas dengan Dinas Ketahanan Pangan, instansi terkait, kelompok yang berpartisipasi dan masyrakat, maka penulis berasumsi bahwa impelemtasi Kebijakan Ketahanan Pangan dan Gizi di Kabupaten Subang dilihat dari indikator kecenderungan pelaksana belum berjalan optimal, hal ini dilihat dari: Pemahaman mereka mengenai kebijakan Ketahanan Pangan dan gizi yang tidak memahami sepenuhnya.

\section{Kesimpulan}

Berdasarkan hasil penelitian yang dilakukan penulis mengenai Implementasi Kebijakan Ketahanan Pangan dan Gizi di Kabupaten Subang masih banyak memiliki kendala yang terjadi, baik diakibatkan dari internal Dinas Ketahanan Pangan maupun eksternal Dinas Ketahanan Pangan seperti dengan Dinas Pertanian, Dinas Perikanan, Dinas Peternakan dan Kesehatan Hewan, Dinas Kesehatan, Dinas Pemberdayaan Masyarakat dan Desa, Dinas Koperasi, UMKM, Perdagangan dan Perindustrian, Badan Perencanaan, Pembangunan, Penelitian, dan Pengembangan Daerah selaku stakeholder. Sesuai dari kesimpulan keenam dimensi menurut Van Meter dan Horn dalam (Winarno, 2016: 142-150) di atas dapat dilihat bahwa Implementasi Kebijakan Ketahanan Pangan dan Gizi di Kabupaten Subang masih mengalami masalah dari beberapa dimensi implementasi. Berdasarkan hasil penelitian penulis diatas mengenai Implementasi Kebijakan Ketahanan Pangan dan Gizi di Kabupaten Subang belum optimal, hal ini dilihat dari dimensi:

1. Ukuran-ukuran dasar dan tujuan-tujuan kebijakan belum berjalan optimal. hal ini dikarenakan tidak semua Desa/Kelurahan yang mengalami rawan pangan dan stunting mendapatkan bantuan. Dalam satu tahun hanya 3 atau 6 Kecamatan yang mendapatkan bantuan, itu pun dari satu kecamatan hanya satu Desa/Kelurahan yang difasilitasi bantuan.

2. Sumber-sumber kebijakan yang belum optimal. ini dikarenakan di Kabupaten Subang tidak memiliki Cadangan Pangan Pemerintah Daerah, kendaraan Dinas yang kurang hal ini dikarenakan sumber daya anggaran 
yang relatif kecil dan tidak didukung sumber daya manusia yang kompeten dalam bidang ketahanan pangan.

3. Karakteristik badan pelaksana yang masih belum optimal. Hal ini disebabkan karena struktur organisasi yang terkait dalam proses Implementasi Kebijakan Ketahanan Pangan dan Gizi di Kabupaten Subang ketua atau yang di sebut dengan Dewan Ketahanan Pangan tidak pernah ada tindakan yang signifikan dan komitmen pelaksana yang rendah karena mereka hanya melaksanakan kegiatan tanpa memikirkan dampak yang akan dirasakan oleh masyarakat.

4. Kondisi sosial, ekonomi dan politik yang belum optimal. karena masyarakat yang menjadi kelompok sasaran masih berpendapatan rendah sehingga mereka tidak akan memeperhatikan asupan gizi yang seimbang. Partisifasi masyarakat kurang dan tidak bisa memanfaatkan bantuan dari pemerintah.

5. Kecenderungan Pelaksana belum optimal. hal ini dilihat dari pemehaman mereka tentang Kebijakan Ketahanan Pangan dan Gizi belum memahami sepenuhnya.

Adapun saran terkait mengenai Implementasi Kebijakan Ketahanan Pangan dan Gizi di Kabuapaten Subang adalah sebagai berikut:

1. Diharapkan pemerintah khusunya agen pelaksana di tingkat Kabupaten agar memberikan bantuan itu kesemua daerah-daerah yang rawan pangan, stunting, dan dibawah garis kemiskinan dan dalam satu kecamatan difasilitasi semua tidak hanya satu Desa/Kelurahan.

2. Diupayakan untuk meningkatkan sumber-sumber kebijakan seperti sarana dan prasarana, sumberdaya anggaran, dan khususnya sumberdaya manusia diberikan pelatihan-pelatihan di bidang ketahanan pangan.

3. Diharapkan Dewan Ketahanan Pangan sebagai Ketua memberikan kontribusi dalam pelaksanaan Kebijakan Ketahanan Pangan dan Gizi di Kabupaten Subang dan para pelaksana seyogyanya meningkatkan komitemen yang tinggi dengan memperhatikan dampak yang akan dirasakan oleh masyarakat setelah melaksanakan kegiatan.

4. Diharapkan Pemerintah bisa memberdayakan masyarakat sehingga dapat membantu secara ekonomi agar mereka bisa meningkatkan penghasilan mereka dan memberikan pelatihan kepada masyarakat agar bisa memanfaatkan bantuan dari Pemerintahan.

5. Diharapkan para pelaksana mempelajari dan memahami isi dari Kebijakan Ketahanan Pangan dan Gizi karena mereka sebagai implementor menjadi kunci keberhasilan dari Implementasi Kebijakan Ketahanan Pangan dan Gizi di Kabupaten Subang 


\section{Referensi}

Agustino, Leo, Ph.D. 2017. Dasar-dasar Kebijakan Publik. Bandung : Alfabeta

Almatsier, Sunita. 2004. Prinsip Dasar Ilmu Gizi. Jakarta : PT Gramedia Pustaka Utama

Dewi, Rahayu K. 2016. Studi analisis kebijakan. Bandung; Pustaka Setia

Dunn, William N. 2013. Pengantar Kebijakan Publik. Edisi ke-2. Yogyakarta : Gajah Mada University Press

Hikam, Muhammad As. 2015. Memperkuat Ketahanan Pangan Demi Masa Depan Indonesia 2015-2025. Jakarta : CV Rumah Buku

Hikmawan, M. D. (2017a). Pluralisme Demokrasi Politik di Indonesia. Journal of Governance, 2(2), 223-247.

https://doi.org/http://dx.doi.org/10.31506/jog.v2i2.2678

Hikmawan, M. D. (2017b). Politik Perbedaan: Minnoritas dalam Implementasi

Kebijakan. Journal of Indonesian Public Administration and Governance Studies (JIPAGS), 1(1), 88-98.

Ibrahim. 2018. Metodologi Penelitian Kualitatif. Bandung: Alfabeta

Keban, Yeremias T. 2014. Enam Dimensi Strategis Administrasi Publik: Konsep, Teori, dan Isu Edisi Ketiga. Yogyakarta: Gava Media

Laporan Akhir Pemantauan dan Analisis Pola Pangan Harapan Kabupaten Subang Tahun 2018

Nugroho, Riant. 2014. Public Policy : Teori Manajemen, Dinamika Analisis, Konvergensi dan Kimia Kebijakan. Jakarta : Elex Media Komputindo

Pasolong, Harbani. 2017. Teori Administrasi Publik. Bandung : Alfabeta

Peraturan Pemerintah Nomor 17 Tahun 2015

Rencana Strategis (RENSTRA) Dinas Ketahanan Pangan Kabupaten Subang 2018-2023

Rusli, Budiman. 2013. Kebijakan Publik : Membangun Pelayanan Publik yang Responsif. Bandung : CV Adoya Mitra Sejahtera

Sugiyono. 2014. Metode Penelitian Administrasi. Bandung : Alfabeta

Sugiyono. 2017. Metode Penelitian Kuantitatif, Kualitatif, dan RED. Bandung : Alfabeta

Syafiie, Inu Kencana. 2010. Ilmu Administrasi Publik (Edisi Revisi). Jakarta : PT Bineka Cipta

Thoha, Miftah 2008. Ilmu Administrasi Publik Kontemporer. Jakarta : Kencana Prenanda Media Group

Undang-Undang Nomor 18 Tahun 2012 Tentang Pangan 
Wahab, Solichin Abdul. 2012. Analisa Kebijakan Dari Formulasi Ke Penyusunan Model-Model Implementasi Kebijakan Publik. Jakarta : Bumi Aksara

Widiyanto, A., Hikmawan, M. D., \& Riswanda, riswanda. (2019). JSPG: Journal of Social Politics and Governance Implementasi Rencana Aksi Nasional Bela Negara Berdasarkan Instruksi Presiden Nomor 7 Tahun 2018 Oleh Dewan Ketahanan Nasional Republik Indonesia. Journal of Social Politics and Governance, 1(2), 95-115.

Winarno, Budi. 2014. Kebijakan Publik: Teori, Proses, dan Studi Kasus. Yogyakarta : Center of Academic Publishing Service 